\title{
EFFECTS OF HOOK AND BAIT ON TARGETED AND BYCATCH FISHES IN AN EQUATORIAL ATLANTIC PELAGIC LONGLINE FISHERY
}

\author{
Rui Coelho, Miguel N Santos, and Sérgio Amorim
}

\begin{abstract}
We examined the effects of different hook style and bait type combinations on the catches of targeted, bycatch, and discarded fishes in equatorial Atlantic waters. In total, 221 longline sets ( $>305,000$ hooks) were deployed from Portuguese pelagic longline vessels (SELECT-PAL Project) during the February-October fishing season. Three different hook styles and two bait types were tested: the traditional J-hook was compared to two circle hooks (one non-offset and one with $10^{\circ}$ offset), and squid bait was compared to mackerel. Catch per unit effort (CPUEs) were calculated and compared between the different hook style and bait type combinations, which indicated that the effects of hook style and bait on the CPUEs were species-specific. For example, swordfish CPUEs were higher with J-hooks baited with squid, while for targeted tunas and blue shark only the bait effect was significant, but with opposite effect (i.e., higher catches of tuna with squid bait and higher catches of blue shark with mackerel bait). For the discarded species, at-haulback mortality was also species-specific. Proportions of alive vs dead specimens at time of fishing gear retrieval did not vary significantly by hook style or bait type combinations. The total retained catch was analyzed in value per unit effort (VPUE), and indicated losses in fishery revenue when mackerel was used instead of squid, but not when circle hooks were used instead of J-hooks.
\end{abstract}

Pelagic longlines are used throughout the world's oceans to target many pelagic fish species, especially large pelagic bony fishes such as swordfish (Xiphias gladius Linnaeus, 1758) and tunas (Thunnus spp.; Soykan et al. 2008). Although longlines are more selective than other fishing gears (e.g., trawls), drifting pelagic longlines catch a wide variety of bycatch, the unintended non-target organisms that are captured during fishing operations (Lewison et al. 2004). In recent years, there has been increased concern with regard to bycatch (Soykan et al. 2008), and several recent studies have addressed this issue. Most bycatch studies have focused on the more vulnerable and charismatic marine "megafauna," including sea turtles (e.g., Watson et al. 2005, Gilman et al. 2006, Epperly et al. 2012, Stokes et al. 2012), sea birds (e.g., Bugoni et al. 2008, Gilman et al. 2008, Li et al. 2012), and sharks (e.g., Yokota et al. 2006, Godin et al. 2012).

Some of the most common strategies to reduce bycatch in pelagic longline fisheries involve gear modifications such as changes in hook style and bait type. Different studies have yielded conflicting results (e.g., review paper by Read 2007) and, in some cases, the gear modifications can reduce the catches of the target species to such a degree that their use is impractical [e.g., the case study of the mahi-mahi fishery in Ecuador reported by Largarcha et al. (2005)]. Therefore, the efficiency of such gear modifications is not only taxon-specific, but also depends on the particular fishery and fishing fleet. Given these complexities that involve possible modifications to 
fishing gear, researchers have recommended different approaches. While Read (2007) recommends that bycatch mitigation measures (including gear modifications) should be tested in rigorous experiments before they are required in any fishery, Serafy et al. (2009) considered that this perspective is counter to the precautionary approach. The latter study acknowledged that rigorous field testing is preferable, but also considered that in cases of severely overfished, threatened, or endangered populations, highly complex and time consuming field experimentation should not be a precondition for a given fishery change that could potentially benefit those populations.

The Portuguese pelagic longline fishery targeting swordfish began in the 1970s. The fishing method has remained nearly unchanged since then, with just a few minor changes incorporated in the last decade. Specifically, fishermen shifted from "traditional gear" to "modern gear" (for gear description, see Watson and Kerstetter 2006) making use of mainlines and gangions of monofilament and using lightsticks or flashlights. In certain areas and seasons, pelagic sharks may be a major component and multifilament wire gangions and mackerel bait are used. Overall, however, the J-hook baited with squid remains the traditional combination for this fleet and fishery. Prior to the present study, no circle hooks have been used or tested commercially by the Portuguese fleet apart from some experiments supported by the US Government between 2000 and 2002 in the Azores Archipelago (Bolden and Bjorndal 2005). However, these results have not been published in the literature.

To further extend circle hook research in the Atlantic Ocean, the Portuguese Fisheries and Aquaculture Directorate and a private fishing company funded an ongoing project (SELECT-PAL: "Redução das capturas acessórias na pescaria de palangre de superfície"). The aim was to test the influence of different hook style and bait type combinations on the catches of target and non-target species caught by the Portuguese pelagic longline fishery operating in three major areas of the Atlantic Ocean: Northeast Tropical, Equatorial, and Southern Temperate. The present study reports the catch composition, catch rates, size, and mortality at haulback of retained and discarded fish species encountered during experimental fishing trials in equatorial waters.

\section{MAterials AND Methods}

Experimental Design and Data Collection.-A total of 221 experimental longline sets were deployed within the equatorial Atlantic region between January 2009 and March 2011. Two commercial fishing vessels from the Portuguese pelagic longline fleet were utilized, with the experimental fishing conducted between $42^{\circ} \mathrm{W}$ and $9^{\circ} \mathrm{E}$ longitude, and between $7^{\circ} \mathrm{N}$ and $7^{\circ} \mathrm{S}$ latitude (Fig. 1). The fishing gear was similar for both vessels, with fishing occurring $20-50 \mathrm{~m}$ below the surface, and consisting of a standard monofilament polyamide mainline (3.6 mm diameter; approximately $55 \mathrm{~nm}$ long), with five branch lines between floats. Each branch line was $18 \mathrm{~m}$ in length, the first part consisting of $2.5 \mathrm{~mm}$ monofilament ( $9 \mathrm{~m}$ long) connected by a swivel to a gangion of $2.2 \mathrm{~mm}$ monofilament (9 $\mathrm{m}$ in length). A battery-powered flashlight (green light) was attached to each gangion. Gear deployment typically began at 17:00 hrs, with haulback starting the next day from about 06:00 hrs.

Experimental fishing focused on hook style and bait type, whereby three different stainless steel hook styles (manufacturer: WON YANG, Korea) were used in each longline set. The control was the traditional J-hook used by the fishery (Model EC-9/0-R), and the treatments were either a G-hook (non-offset circle hook Model H17/0-M-S) or a Gt-hook (10 offset circle hook Model H17/0-M-R). See Table 1 for details on hook specifications (a photograph of the hooks appears in Santos et al. 2012). Hook styles were alternated section by section (each 


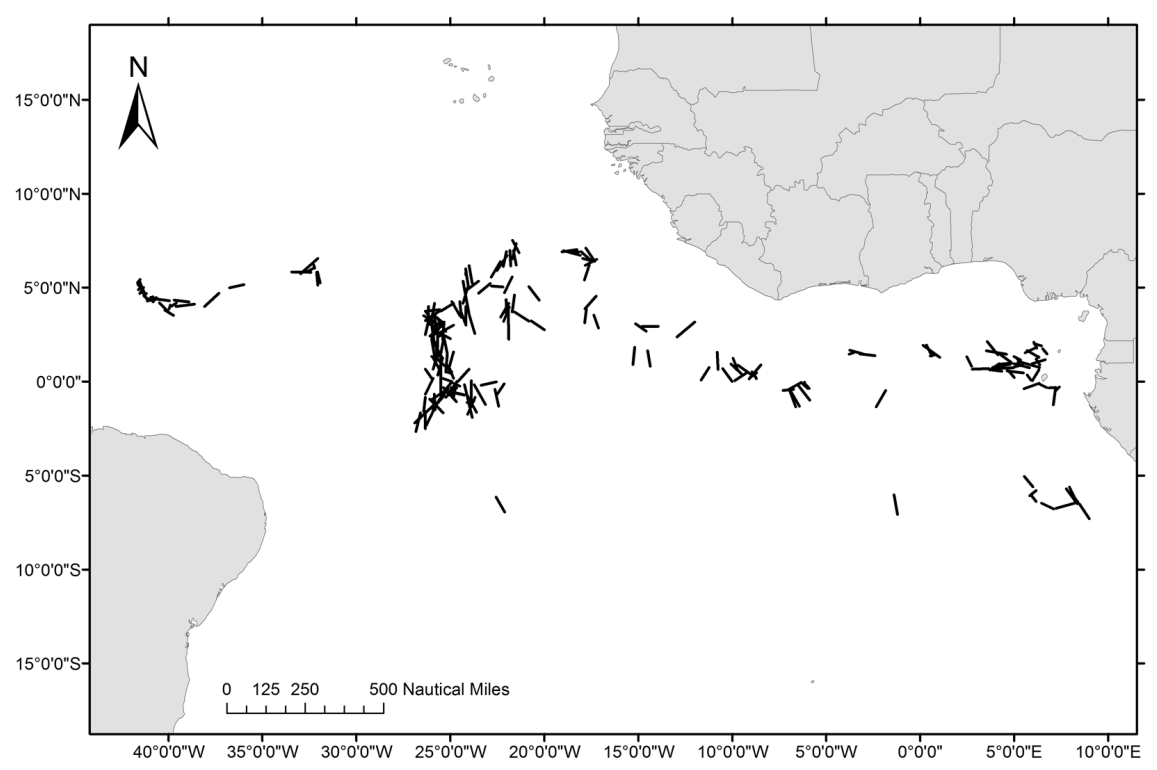

Figure 1. Location of the 221 experimental longline sets in the equatorial Atlantic region.

containing 70-80 hooks) of the longline, to minimize the potentially confounding effects specific to each set (e.g., location, water temperature, or other factors). In addition, the hook style of the first section in the water was changed every set, following a fixed scheme (J, G, Gt, J, G, Gt, ... etc.). Two different bait types were used, mackerel (Scomber spp.) and squid (Illex spp.), but only one bait was used in each set. Consistent bait size lengths were used in all longline sets (squid $27.8 \pm 0.97 \mathrm{~cm}$ and mackerel $35.1 \pm 1.19 \mathrm{~cm}$ ).

All characteristics of the fishing gear and fishing practices (e.g., hook placement, setting time, use of light, bait size, and hook manufacturer) were consistent between the two vessels. However, length of mainline and number of hooks varied between vessels, according to the operating capacity of each vessel and sea conditions. All data were recorded by onboard fishery observers. For every set, location (longitude and latitude), date, and number of hooks of each hook style was recorded. For every fish captured, the hook style and bait type were recorded, the species was identified, and the fork length (FL) of each specimen was measured to the nearest $\mathrm{cm}$. Additional information was recorded on sex (for elasmobranchs), condition at haulback (alive/dead), specimen's fate (retained/discarded), and its condition if discarded (alive/dead).

Table 1. Details of the different hook styles used in the study. Standard deviation is indicated within parentheses. J is traditional hook used in fishery, G and Gt are circle hooks with no offset and $10^{\circ}$ offset, respectively.

\begin{tabular}{lccc}
\hline & \multicolumn{3}{c}{ Hook style } \\
\cline { 2 - 4 } Parameter & $\mathrm{J}(\mathrm{EC}-9 / 0-\mathrm{R})$ & $\mathrm{G}(\mathrm{H} 17 / 0-\mathrm{M}-\mathrm{S})$ & $\mathrm{Gt}(\mathrm{H} 17 / 0-\mathrm{M}-\mathrm{R})$ \\
\hline Total length $(\mathrm{mm})$ & $87.2( \pm 1.11)$ & $77.7( \pm 0.92)$ & $77.7( \pm 0.92)$ \\
Front length $(\mathrm{mm})$ & $40.4( \pm 1.10)$ & $43.9( \pm 0.45)$ & $43.9( \pm 0.45)$ \\
Maximum width $(\mathrm{mm})$ & $43.3( \pm 0.64)$ & $49.4( \pm 0.88)$ & $49.4( \pm 0.88)$ \\
Gap $(\mathrm{mm})$ & $33.2( \pm 0.59)$ & $27.0( \pm 0.51)$ & $27.0( \pm 0.51)$ \\
Arm diameter $(\mathrm{mm})$ & $5.0( \pm 0.00)$ & $5.0( \pm 0.00)$ & $5.0( \pm 0.00)$ \\
Offset angle & $10^{\circ}$ & $0^{\circ}$ & $10^{\circ}$ \\
\hline
\end{tabular}


Fish catches were placed into three categories depending on the species: target, bycatch, or discard. For this fishery and using these specific fishing techniques, the main target species was swordfish, with bigeye tuna and yellowfin tuna considered minor target species (Appendix 1). Bycatch was retained when valuable and included species such as other tunas, billfishes, large pelagic sharks, and other teleosts (Appendix 1). Bycatch such as small-sized elasmobranchs, teleosts with no commercial value, and larger prohibited elasmobranchs (e.g., thresher sharks) were discarded (Appendix 1).

Data AnAlysis.-CPUE was estimated as catch in weight (kg) per 1000 hooks. CPUE data for discarded species were also estimated per 1000 hooks, but using the number of specimens discarded instead of captured biomass. CPUEs were calculated for each species in each fishing set (including sets with zero catches) and those values were used to calculate the mean CPUE with the respective standard deviations for each hook-bait combination. Frequency of occurrence (presence-absence per set) was calculated for each species for each hook-bait combination. The total retained catch value per unit effort (VPUE, calculated as the value in Euros per 1000 hooks) was also calculated for each hook style and bait type combination. The reference values for the VPUE calculation were those in the Vigo (Spain) market during December 2010 for frozen products.

CPUE and VPUE data were tested for normality with Kolmogorov-Smirnov tests with Lilliefors correction (Lilliefors 1969) and for homogeneity of variances with Levene tests. In cases where data lacked normality and homogeneity of variances, non-parametric KruskalWallis and Mann-Whitney tests were employed to test for differences between the three hook styles and the two bait types, respectively.

For swordfish, a generalized linear model (GLM) for the response variable CPUE was applied using bait type and hook style as explanatory variables. Given that the response variable (CPUE) is a continuous variable with a discrete mass at 0 (corresponding to the fishing sets with zero catches), a Tweedie distribution with a log link function was used in the GLM. The Tweedie distribution is part of the exponential family of distributions, and is defined by a mean $(\mu)$, and a variance $\left(\phi \mu^{p}\right)$ in which $\phi$ is the dispersion parameter and $p$ is the index parameter. When the index parameter has values between 1 and 2, the distribution is continuous for positive real numbers, but has an added discrete mass at 0 , which is appropriate when modeling CPUE data (Shono 2008). The baseline reference levels for the covariates were J-hooks baited with squid, and the other levels of the covariates were compared against this combination. Given that the log link function was used, the odds ratios for model interpretation were calculated as the exponential values of the estimated parameters.

The size distribution of the three target species and the most abundant bycatch species were compared among the different hooks styles and bait types. For each combination, the mean FL and its respective standard deviation was calculated. Non-parametric Kruskal-Wallis tests were used to compare the fish sizes among hooks styles and Mann-Whitney tests were used to compare the fish sizes between bait types.

The mortality at time of fishing gear retrieval (at haulback) was assessed for discarded species. The proportions of live individuals of each species were calculated for each hook style and bait type combination, and differences in the proportions between hooks and baits were tested with contingency tables and chi-square proportion tests. This analysis was only carried out for the most frequently caught discard species and was not performed in cases where there were cells in the contingency tables with zero values. For these specific cases, the data on hook style were combined into two categories (J- and circle hooks-combining G and Gt) to avoid cells with zero values in the contingency tables.

Data analyses for this paper were carried out using the R Project for Statistical Computing version 2.13.0 ( $\mathrm{R}$ Development Core Team 2011). Most analyses used functions available in the core $\mathrm{R}$ program. Exceptions were the Levene test to compare homogeneity of variances that uses library "car" (Fox and Weisberg 2011), and the GLM fitting using the Tweedie distributions that uses functions available in library "tweedie" (Dunn 2010), including the maximum likelihood estimation of the index parameter. 


\section{RESULTS}

Description of the Catches.-Overall, 305,352 hooks were deployed during the fishing trials (221 sets), corresponding to 101,784 hooks of each hook type. The vessels fished a mean of 1381 hooks per set; the minimum number of hooks fished in a set was 1260 and the maximum was 1728 hooks. In terms of bait, a total of 143,136 hooks were baited with mackerel, while the remainder 162,216 were baited with squid. The minimum and the maximum number of hooks used in each of the different hook style-bait type combinations were 47,712 and 54,072, respectively. The sea surface temperatures (SST) ranged between 21 and $29^{\circ} \mathrm{C}$, with a mean of $26.6^{\circ} \mathrm{C}$ and a standard deviation of $1.97^{\circ} \mathrm{C}$.

In total, 28 fish taxa were captured and recorded during the present study (Appendix 1). Of those, three (swordfish, bigeye tuna, and yellowfin tuna) were considered the target species, 17 were assigned as bycatch (10 teleosts and seven elasmobranchs), and the remaining eight taxa were discards (among these, two were teleosts and six were elasmobranchs).

The frequency of occurrence varied greatly depending on species, hook style, and bait. The most frequently-caught species in the fishery was the blue shark (a bycatch species), representing a total of $53 \%$ of the total catch in weight and occurring in $82.2 \%$ of the sets. The blue shark, combined with swordfish, represented around $76 \%$ of the overall retained catch (in weight). Swordfish occurred in $78.3 \%$ of the sets, with this percentage sharply decreasing for the targeted tunas (i.e., $35.4 \%$ and $22.8 \%$ for bigeye and yellowfin tuna, respectively).

Effects of Hook and Bait on Retained CAtch.-The effects of the various hook styles and bait types appeared taxon-specific, with the catch rates varying according to the six hook-bait combinations tested (Table 2). For the aggregate of target species, the highest catch rates were obtained with squid, with no significant differences among hook types. Substantially lower catch rates were obtained when mackerel was used instead of squid. Analyzing the target species individually, both hook style and bait affected swordfish catch rates, whereas for the tunas, bait type was more important than hook style (Fig. 2). Testing for the individual effects of these factors revealed that the use of squid as bait resulted in significantly higher catches of all three target species, while the use of J-hooks significantly increased catches in only swordfish (Table 2).

There were species-specific differences for the non-target species that were retained, with the overall teleost bycatch rates being highest with J-hooks baited with squid, and the overall elasmobranch bycatch rates being highest with circle hooks baited with mackerel. The overall bycatch rate of teleosts and elasmobranchs was also highest for circle hooks baited with mackerel, but those results are highly influenced by the elasmobranch component of the bycatch that constituted the majority of the bycatch in weight (Table 2). In terms of the overall VPUE of the total retained catch, significant differences were detected when changing bait type from squid to mackerel (Mann-Whitney: $W=44480, P<0.001$ ), but not when changing from J-hooks to circle hooks (Kruskal-Wallis: chi-square $=0.339, \mathrm{df}=2, P=0.84$; Table 2).

Several non-target species that were retained were analyzed individually, either due to their relatively high commercial value or to the quantity of bycatch in weight (i.e., marlins, sailfish, blue shark, silky shark, shortfin mako, oceanic whitetip, and 


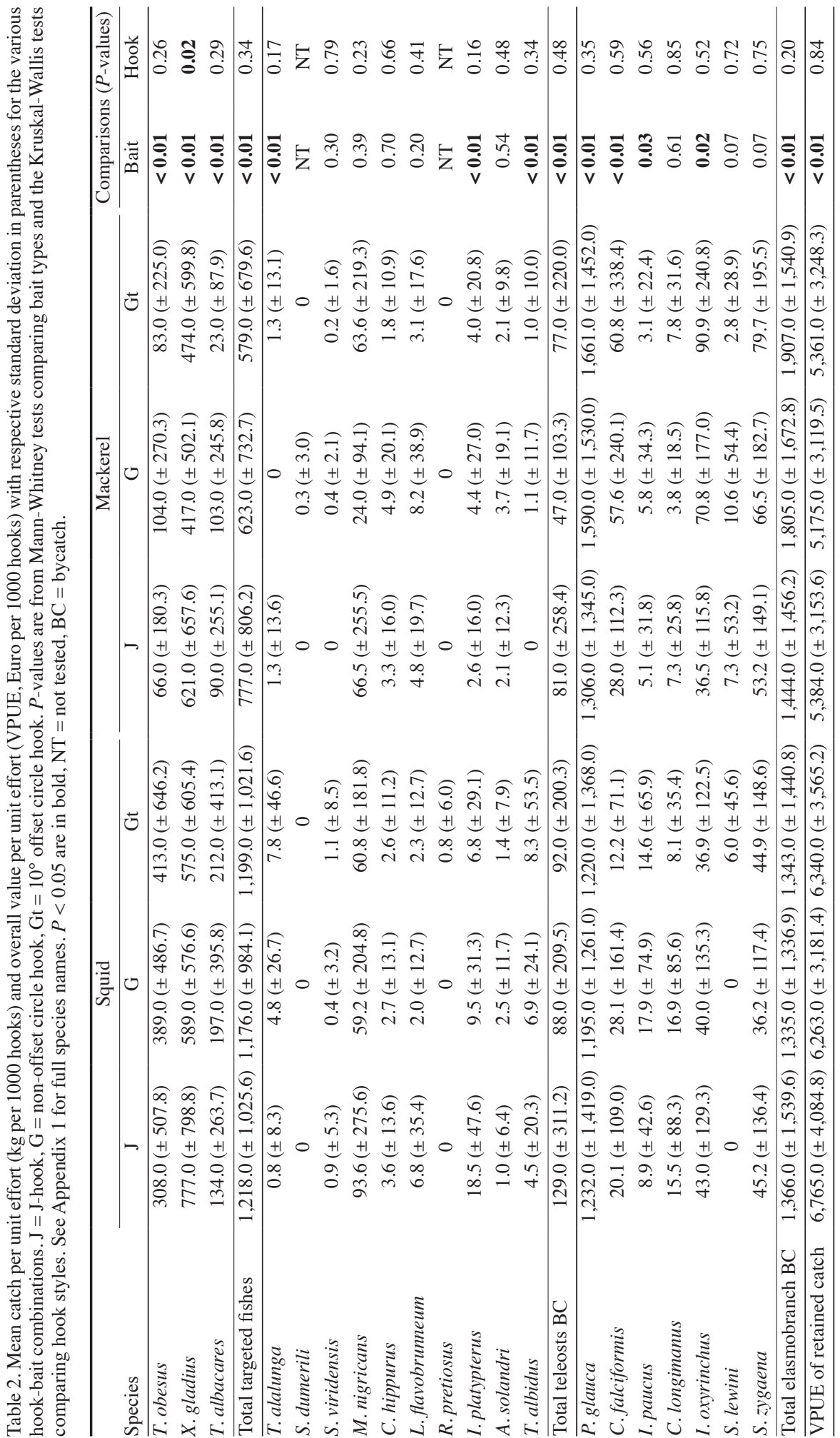



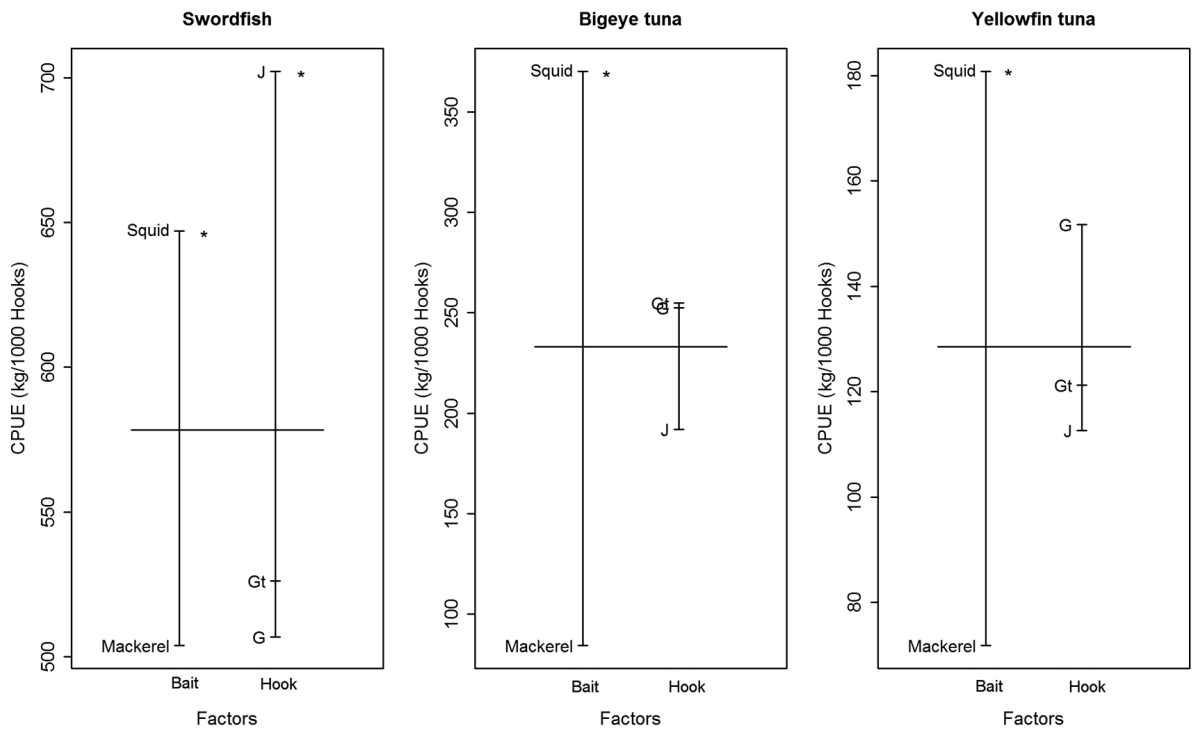

Figure 2. Effects of hook style [J-hook (J), non-offset circle hooks $(\mathrm{G}), 10^{\circ}$ offset circle hooks (Gt)] and bait type (squid vs mackerel) on the catch rates (CPUE) of the three targeted species in this fishery: swordfish, bigeye tuna, and yellowfin tuna. The vertical lines represent the range of values while the horizontal line represents the overall mean across all observations. Both bait and hook effects were significant $(*)$ for swordfish. Only bait effects were significant for the two tuna species.

smooth hammerhead). Non-parametric statistical comparisons indicated that the only significant factors were the effect of bait (i.e., higher with squid) on the catch rates of white marlin, sailfish, and albacore (Table 2, Fig. 3). The effects tended to be opposite for elasmobranch bycatch, with most species having higher catch rates with circle hooks (not significant) baited with macheral (Fig. 4). Only bait type was significant for most elasmobranchs (Table 2).

Hook style and bait type were significant covariates for the swordfish catch rates (Fig. 2, Table 2). By applying the tweedie distribution to model swordfish catch rates along with these two explanatory variables, we confirmed that both hook style and bait type significantly influenced CPUE (Table 3). In terms of parameter interpretation, the catch rates of swordfish with circle hooks were lower than with J-hooks, by factors of 0.72 ( $95 \%$ CI between 0.59 and 0.88$)$ and 0.75 (95\% CI between 0.61 and 0.92 ), for hook styles $\mathrm{G}$ and Gt, respectively (Table 3). This represents an expected reduction in the catch rates of approximately $25 \%$ when changing from J- to circle hooks, with $95 \%$ confidence intervals varying between approximately $10 \%$ and $40 \%$. In terms of bait type, the catch rates with mackerel compared to squid were lower by a factor of $0.78(22 \%)$, with $95 \%$ confidence intervals varying between $8 \%$ and $34 \%$ (Table 3).

Size Distribution of Retained Species.-In general, mean sizes for the three target species and the blue shark were relatively similar between different hook styles and bait types (Table 4). The only cases where significant differences were detected in size distribution were for yellowfin tuna and blue shark when comparing bait types, and for the bigeye tuna when comparing hook styles (Table 4). The mean size of yellowfin tuna and blue shark caught with mackerel was slightly lower than with squid. In the case of the bigeye tuna, mean size with circle hooks was slightly lower than the catches with J-hooks. 

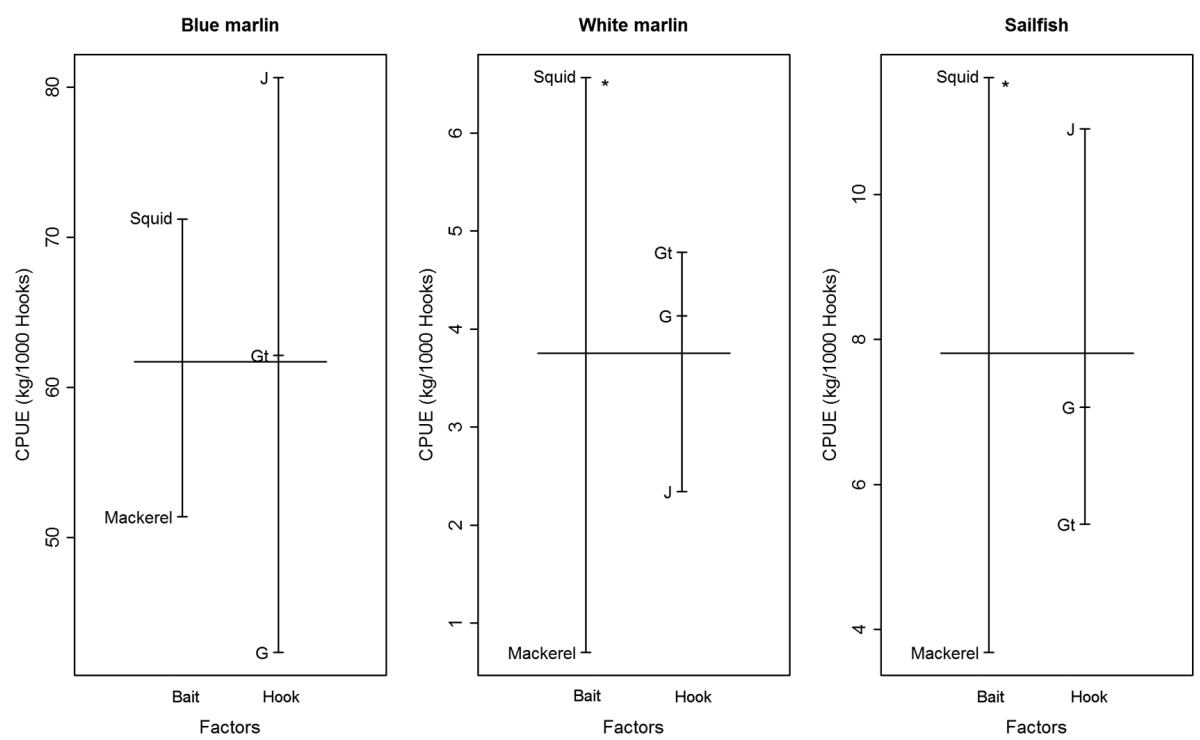

Figure 3. Effects of hook style [J-hook (J), non-offset circle hooks $(\mathrm{G}), 10^{\circ}$ offset circle hooks (Gt)] and bait type (squid vs mackerel) on the catch rates of the three main teleost bycatch species in the fishery: blue marlin, white marlin, and sailfish. The vertical lines represent the range of values while the horizontal line represents the overall mean across all observations. Only bait effects were significant $(*)$ for white marlin and sailfish.

Catch Rates and Mortality of Discarded Species.-As observed with other large pelagic sharks, the catch rates of bigeye thresher were significantly higher when mackerel bait was used instead of squid, but no significant differences were detected between J- and circle hooks (Table 5). In contrast, the catch rates of manta rays (Manta spp.), pelagic stingray, and crocodile shark were significantly higher with squid than with mackerel. The only significant difference detected for hook style was for pelagic stingray, which had highest catch rates with J-hooks (Table 5).

The mortality rates (at haulback) of the discards were taxon-specific and appeared unrelated to hook style (Table 6). Regardless of the hook style used, most of the bigeye thresher sharks were dead at haulback, while most of the manta rays, pelagic stingrays, and crocodile sharks were alive at haulback. Chi-square tests confirmed that within each species, the proportions of dead and alive specimens were similar when comparing different hook styles (chi-square proportion tests: $P>0.05$ in all cases; Table 6). In the above analysis, and for bigeye thresher and pelagic stingray, both circle hooks (G and Gt) were grouped into one category (circle hook) to avoid cells with zeros in the contingency tables. We were unable to perform this analysis for the manta rays due to cells with zero values in the contingency table, even after grouping the two circle hooks into a single category.

Condition of the catches also appeared to be independent of the bait type. The chi-square proportions tests (applying the Yates' continuity correction given that the contingency tables are of the $2 \times 2$ type) did not detect significant differences in the proportions of dead and alive specimens at haulback with the two baits types (chisquare proportion tests: $P>0.05$ in all cases). 


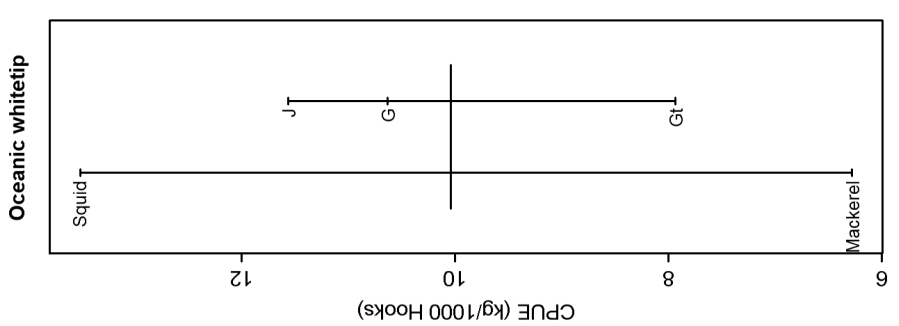

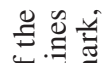

प्न

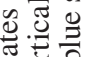

可?

范

记实

눙 宅泀

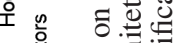

若

ब)

可. क

寻

छ U

$>0 \frac{n}{0}$

¿

政

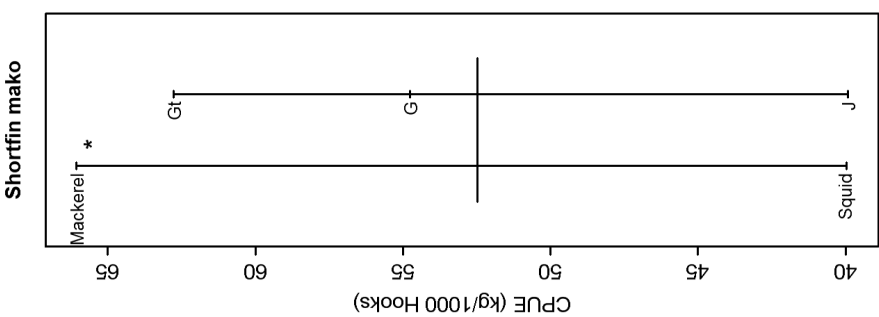

늠

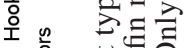

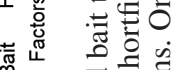

若 ّँ

สี

氕完

क है

흥 छ클

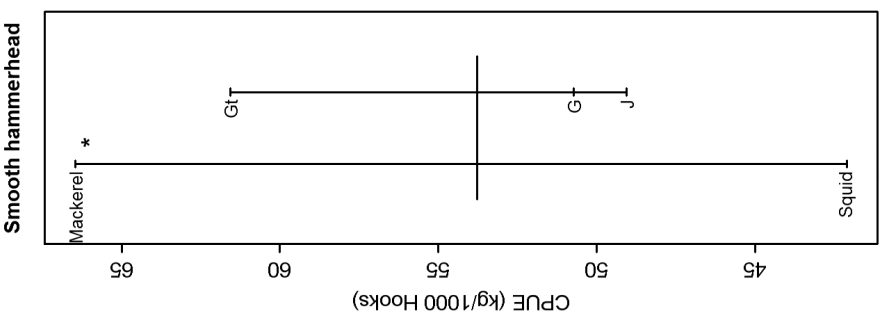

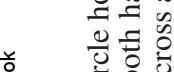

오 흥응

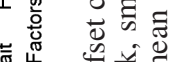

䒢

$\circ$ 的

$\rightarrow 0$

कิำ

0 क

i

능

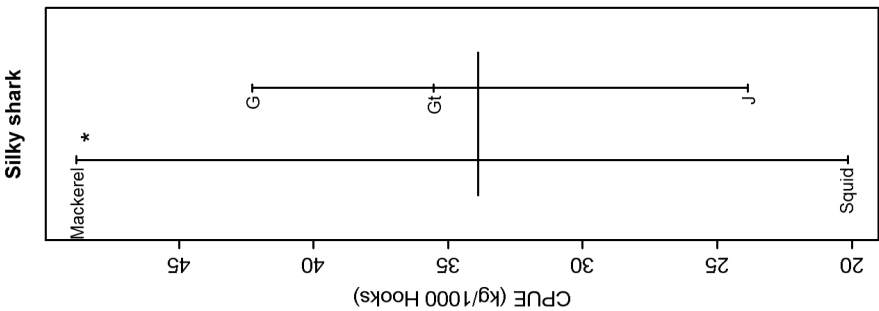

낭

오 은 긍 흥

芯芯通过

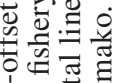
응 옹

$\because \Xi$

S.

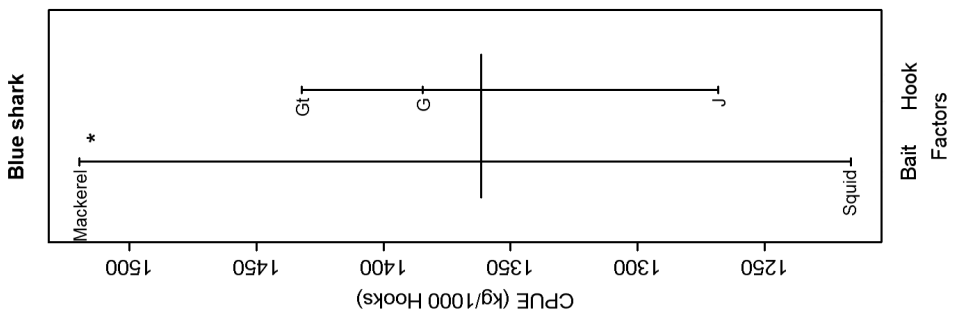

능 응

됴용

둥

익

ते की

40

웅

펑ㄷ

항 을

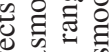

(2)

피리

+크류

ㄹ

500 0

诖 융 
Table 3. Coefficients for the swordfish CPUE Tweedie GLM with the odds-ratios, considering the covariates hook style and bait type. Listed are the parameter estimation of the model, the standard errors (SE), the Wald Statistic, and the respective $P$-values. For the odds-ratios, listed are the point estimate with the lower and upper $95 \%$ confidence intervals $(\mathrm{CI})$.

\begin{tabular}{|c|c|c|c|c|c|c|c|}
\hline \multirow[b]{2}{*}{ Parameter } & \multicolumn{4}{|c|}{ Coefficients } & \multicolumn{3}{|c|}{ Odds-ratios } \\
\hline & Estimate & SE & Wald & $P$-value & Estimate & Lower CI & Upper CI \\
\hline (intercept) & 6.67 & 0.08 & 84.9 & $<0.01$ & & & \\
\hline Non-offset circle hook (G) & -0.33 & 0.10 & -3.2 & $<0.01$ & 0.72 & 0.59 & 0.88 \\
\hline $10^{\circ}$ offset circle hook $(\mathrm{Gt})$ & -0.29 & 0.10 & -2.8 & $<0.01$ & 0.75 & 0.61 & 0.92 \\
\hline Bait type mackerel & -0.25 & 0.09 & -2.9 & $<0.01$ & 0.78 & 0.66 & 0.92 \\
\hline
\end{tabular}

\section{DISCUSSION}

This is the first study on the effects of hook style and bait type on the catch rates of targeted, bycatch, and discarded fish species in the Portuguese pelagic longline fishery operating in Atlantic equatorial waters. Santos et al. (2012) concluded that changing from J- to circle hooks and from squid to mackerel bait were efficient measures for reducing bycatch of sea turtles, particularly for the olive ridley (Lepidochelys olivacea Eschscholtz, 1829), which is globally the most abundant sea turtle species (Abreu-Grobois and Plotkin 2008). However, the issue of what such changes would represent for the remaining catches of the fishery, particularly for the fishes (both the retained and the discarded species) remained unanswered. Thus, the goal of our study was to assess the effects of different hook styles and bait type combinations on the catch rates and mortality of all species caught in the fishery.

The main results of the present study were that both the hook style and bait type effects on the catch rates of pelagic fishes are species-specific, and that, in general, the bait appears to be more important than hook style in influencing catch rates. However, due to this taxon-specificity, the results should be evaluated individually in terms of each species or species-complex. For swordfish, the main target species in this fishery, both the hook style and the bait type significantly affected catch. In particular, swordfish catch rates significantly decrease when changing from the traditional hook-bait combination (J-hooks baited with squid) to other combinations. For tunas that are caught and retained by this fishery (either as minor targeted species or as bycatch), the bait type was also significant, with lower catch rates obtained using mackerel vs squid. Bait was also a significant factor in the catch of large pelagic sharks, but had an opposite effect, specifically, higher catch rates with mackerel vs squid. Catch rates of large pelagic sharks and tunas tended to be slightly higher when circle hooks were used, but these differences were not statistically significant.

Other studies have examined the effects of hook style and bait type on the catches of target and bycatch species in other fisheries, fleets, and regions. Kerstetter and Graves (2006a) studied the effects of hook style (9/0 $10^{\circ}$ offset J- vs $16 / 00^{\circ}$ offset circle) in the northwest Atlantic swordfish longline fishery and, as in our study, concluded that the catch rates for most species categories were not significantly different between hook styles, although circle hooks had generally higher catches of tuna (statistically significant for yellowfin tuna), but lower catches of swordfish. Working in the southwest Atlantic Ocean, Pacheco et al. (2011) compared circle $\left(18 / 00^{\circ}\right.$ offset) with J-hooks $\left(9 / 010^{\circ}\right.$ offset) and found no significant differences in the main 


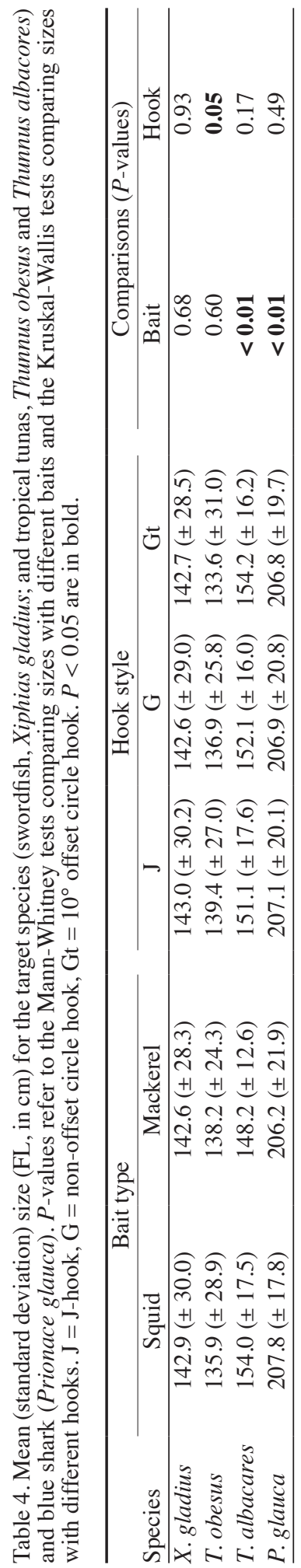




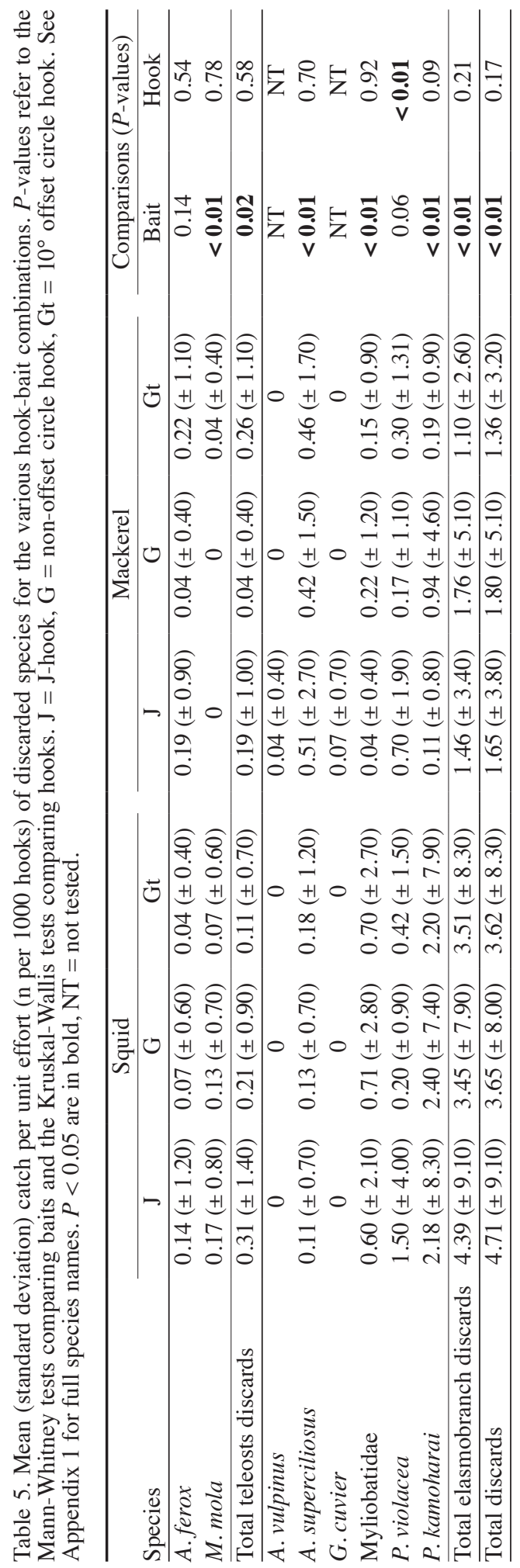




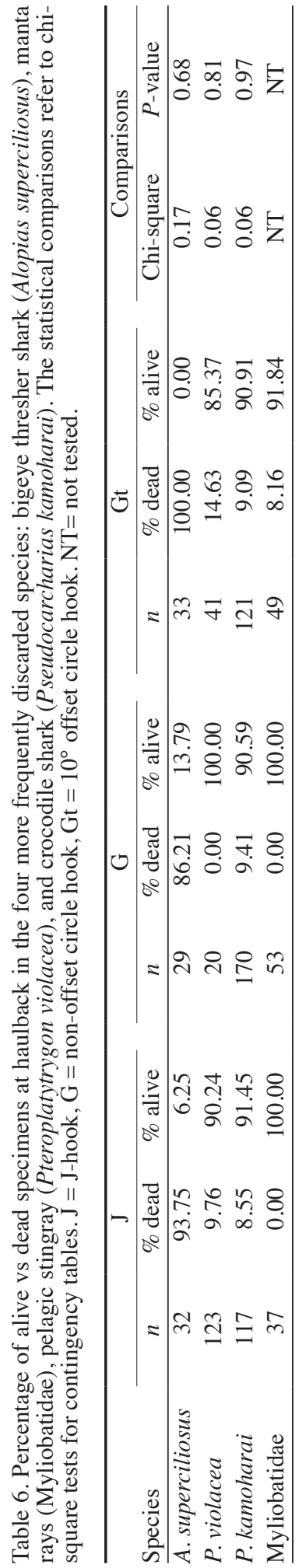


catch composition of the fishery, except that bigeye tuna comprised a significantly higher proportion of the catch with circle hooks, and J-hooks resulted in higher catches of sailfish and the pelagic stingray. In a study designed to address sea turtle bycatch in the northwest Atlantic longline fishery, Watson et al. (2005) concluded that blue shark catches increased with circle hooks (compared to J-hooks) similar to our study, but decreased with mackerel (vs squid), in contrast to our findings. Therefore, it seems that the effects of those factors (hooks style and bait type) are not only taxon-specific, but also possibly location-, fishery-, and fleet-specific. Hence, the importance of testing such gear modifications in experiments designed for specific fisheries and fishing fleets, as recommended by (Read 2007).

Other studies have addressed hook style, but compared circle hooks with tuna hooks, that like J-hooks have the point parallel to the shank. Ward et al. (2009) compared different sized circle hooks (13/0, 14/0, 16/0, and 18/0 with $5^{\circ}$ offset) with tuna hooks (2.8-3.5 sun with $5^{\circ}$ offset) in eastern Australia's tuna and billfish longline fishery, and reported that the catch rates of target species increased with circle hooks. In the same study, these researchers also reported higher catch rates with circle hooks on bycatch species, especially pelagic sharks that are considered at risk. In contrast, Yokota et al. (2006) examined blue shark catches with conventional tuna hooks (standard Japanese 3.8 sun) and circle hooks (4.3 sun and 5.2 sun sizes) in the northwest Pacific longline fishery, and concluded that circle hooks had little impact on blue shark catch rates.

Besides the above hook style comparisons, other studies have addressed mainly bait type. Yokota et al. (2009) focused on the effects of bait type (mackerel and squid) and color (baits dyed in blue and not dyed) on the catch rates of sea turtles and pelagic fishes, including teleosts (swordfish, bigeye tuna, and striped marlin) and sharks (blue shark and shortfin mako). These researchers concluded that unlike the effect on sea turtles (lower catches with mackerel bait vs squid), there were no significant differences in the catch rates of fish species by bait types or color. Those findings are in contrast to ours from the equatorial Atlantic region, where we found significant differences between bait types for all the target, and for most of the bycatch species, including teleosts and elasmobranchs, although with opposite effects.

The tweedie GLM appears to be an appropriate method to model continuous positive data with an added mass of zeros. The tweedie GLM has been used previously with success to model CPUE data (e.g., Candy 2004, Shono 2008), but also to model other types of data with similar structure (e.g., rainfall data by Dunn 2004). While our results for swordfish corroborate what was observed with non-parametric statistical tests, it should be noted that we did not present a complete tweedie GLM. Rather, we explored the influence of potentially important covariates on swordfish catch rates, which in the context of our study, were hook style and bait type, but no residual analysis was performed after model fitting. Thus, we did not explore diagnostics such as the goodness-of-fit of the model, the adequacy of the link function, and the presence of outliers. However, work is currently underway to develop a full model, including additional covariates and model diagnostics with residual analysis for these types of data.

In terms of size at catch, there were significant differences between hook styles for bigeye tuna (with smaller specimens caught with circle hooks), and between baits for the yellowfin tuna and blue shark (with smaller specimens captured with mackerel in both cases). However, actual differences in observed sizes were small, on the order of 
a few cm FL. Most previous studies also found no major differences in the captured sizes when comparing hook styles (e.g., Yokota et al. 2006, Ward et al. 2009), suggesting similar selectivity curves for these species in the upper layers of the water column (<50 m depth).

Most of the discarded species of this fishery are elasmobranchs that are either discarded due to their negligible commercial value (e.g., pelagic stingray and crocodile shark) or due to current management regulations requiring their release (e.g., ICCAT Recommendation 09-07 for thresher sharks). As for other large pelagic sharks, the catch rates of bigeye thresher shark were significantly higher when mackerel was used as bait instead of squid. This was in contrast to that found for manta rays, where higher catch rates tended to be obtained with the traditional squid bait (although low sample sizes precluded analysis).

Mortality rates at haulback were taxon-specific and independent of the hook style used. Regardless of the hook style, species such as the bigeye thresher had very high mortality rates at haulback, while species such as manta rays, the pelagic stingray, and the crocodile shark were mostly captured and discarded alive. Similar results were presented by Ward et al. (2009), who also found that most species had an equal probability of being alive on circle or tuna hooks, including the target species of that fishery (albacore, yellowfin, and bigeye tuna). Specifically for the blue shark, Yokota et al. (2006) also reported no differences in the proportions of dead and alive specimens when comparing circle hooks with tuna hooks. On the other hand, Carruthers et al. (2009) reported that the odds of survival in the Canadian swordfish and tuna longline fishery in the northwest Atlantic were two to five times higher for swordfish, yellowfin tuna, pelagic stingray, porbeagle, and blue shark caught on circle hooks compared to J-hooks. Similarly, Diaz (2008) found that a significantly higher proportion of blue and white marlin was released alive from circle hooks than from J-hooks by the US pelagic longline fleet in the Gulf of Mexico.

Even though we did not find conclusive benefits of circle hooks in terms of athaulback mortality of the discarded species, differences between studies in sample size may have contributed to conflicted results. Compared to the 221 experimental longline fishing sets performed and analyzed during our study, some studies have analyzed smaller data sets [e.g., Ward et al. (2009) with 76 fishing sets, Pacheco et al. (2011) with 81 fishing sets], while others have analyzed considerably larger data sets [e.g., Carruthers et al. (2009) with 859 sets, Diaz (2008) with 1067 sets]. Additionally, it should be noted that we did not record hooking location in the captured specimens, thus we could not compare the proportions of the different hooking locations obtained with each hook style. Cooke and Suski (2004) reviewed recreational fisheries studies evaluating fish mortality with circle and other types of hooks, and concluded that overall mortality rates were consistently lower with circle hooks than with J-hooks, mainly due to the hooking location. In commercial pelagic longline fisheries, Watson et al. (2005) found that circle hooks reduced the mortality associated with fishing interactions for both fishes and sea turtles, mainly because circle hooks were more frequently hooked in the jaw instead of deep-hooked in the gut. Using satellite telemetry to study survival of white marlin released from commercial pelagic longline fisheries in the northwest Atlantic, Kerstetter and Graves (2006b) noted that hooking location was a more important factor than hook type for predicting post-release survival. 
Therefore, even though we found no significant differences in the proportions of at-haulback mortality (for the discarded species) for the different hook styles, it is possible that circle hooks lead to lower post release mortalities due to differences in hooking locations. In general, deeply hooked specimens will die more often than jaw-hooked specimens, mainly due to tissue damage, infection, and possible perforation of the internal organs (Watson et al. 2005). A recent study by Campana et al. (2009) that used satellite telemetry to estimate post-release mortality on blue shark caught by commercial pelagic longlines showed that all specimens that were healthy when released survived, while $33 \%$ of those that were badly injured (i.e., gut hooked) died after being released. On the other hand, recent work by Parga (2012) with deep hooked sea turtles showed that as long as the gangion line was cut short (close to the mouth) deep-hooked sea turtles would often swallow and expel the hooks without major harm.

In terms of VPUE, while bait type significantly influenced the market value obtained, market prices for these target and bycatch species can vary widely and frequently. Likewise, bait costs must be taken into account and these are subject to seasonal fluctuations. Thus, these results should only be regarded as point estimates and any extrapolation for the fishery should take this into consideration. As noted by Campbell and Cornwell (2008), prior to implementing a bycatch reduction device or gear modification in a fishery to reduce bycatch, the human dimensions of such changes should be addressed. In particular, the economic impacts of gear modifications in the fishery should be estimated, as in some cases significant reductions in the target species may hinder their application. Such was the case described by Largarcha et al. (2005) for the mahi-mahi fishery in Ecuador, where changing from traditional hooks to circle hooks was efficient in reducing sea turtle bycatch and mortality, but also reduced the target species catch rates by such high levels (ca. 30\%) that implementation of that gear modification was not economically viable. Similarly, in the Spanish Mediterranean surface swordfish longline fishery, when fishermen used fish bait instead of squid, sea turtle bycatch was reduced, but their economic profit was also diminished (Báez et al. 2010).

For the Portuguese longline fishery in Atlantic equatorial waters, results of our study indicate that changing from J- to circle hooks would reduce bycatches of vulnerable sea turtles (Santos et al. 2012), but simultaneously result in lower catch rates of swordfish, the main target species of the fishery. Such changes may therefore fail to sustatin the economic viability of this pelagic longline fishery, or result in increases in effort that could counteract potential benefits from circle hook use. Our analysis, however, did not indicate that a switch from J-hooks to circle hooks would have a significant impact on the overall value of the retained catch.

\section{ACKNOWLEDGMENTS}

This study was carried out within the scope of the SELECT-PAL project (Programa PROMAR Proj. 31-03-05-FEP-1). Thanks are due to the crews of fishing vessels ALMA LUSA (PN-1269-N) and PRÍNCIPE DAS MARÉS (PM-1218-C) for their cooperation and commitment during the course of the study. Thanks are also due to the technicians (I Ribeiro and J Táta Regala) for collecting the data. We are also grateful to the guest editors of the proceedings and the three anonymous referees for their revisions and comments that have substantially improved this manuscript. R Coelho was partially supported by a grant from FCT (Ref: BDP 40523/2007) cofunded by "POCI-2010 Programa Operacional Ciência e Inovação 2010" and "FSE Fundo Social Europeu." 


\section{Literature Cited}

Abreu-Grobois A, Plotkin P. 2008. Lepidochelys olivacea. In: IUCN 2011 red list of threatened species. Version 2011.1. Available from: www.iucnredlist.org. Accessed 08 July, 2011.

Báez JC, Real R, Mácias D, Serna JM, Bellido J), Camiñas JA. 2010. Captures of swordfish Xiphias gladius Linnaeus, 1758 and loggerhead sea turtles Caretta caretta (Linnaeus, 1758) associated with different bait combinations in the western Mediterranean surface longline fishery. / Appl Ichthyol. 26:126-127. http://dx.dol.org/10.111//.1439-0426.2009.01342.x

Bolden AB, Bjorndal KA. 2005. Experiment to evaluate gear modification on rates of sea turtle bycatch in the swordfish longline fishery in the Azores - Phase 4 Final Project Report. Report presented to the National Marine Fisheries Service. Archie Carr Center for Sea Turtle Research, University of Florida, Gainesville, FL, USA.

Bugoni L, Mancini PL, Monteiro DS, Nascimento L, Neves TS. 2008. Seabird bycatch in the Brazilian pelagic longline fishery and a review of capture rates in the southwestern Atlantic Ocean. Endang Species Res. 5:137-147. http://dx.doi.org/10.3354/esr00115

Campana SE, Joyce W, Manning MJ. 2009. Bycatch and discard mortality in commercially caught blue sharks Prionace glauca assessed using archival satellite pop-up tags. Mar Ecol Prog Ser. 387:241-253. http://dx.doi.org/10.3354/meps08109

Campbell LM, Cornwell ML. 2008. Human dimensions of bycatch reduction technology: current assumptions and directions for future research. Endang Species Res. 5:325-334. http:// dx.doi.org/10.3354/esr00172

Candy SG. 2004. Modeling catch and effort data using generalized linear models, the tweedie distribution, random vessel effects and random stratum-by-year effects. CCAMLR Sci. 11:59-80.

Carruthers EH, Schneider DC, Neilson JD. 2009. Estimating the odds of survival and identifying mitigation opportunities for common bycatch in pelagic longline fisheries. Biol Conserv. 142:2620-2630. http://dx.doi.org/10.1016/j.biocon.2009.06.010

Cooke SJ, Suski CD. 2004. Are circle hooks an effective tool for conserving marine and freshwater recreational catch and release fisheries? Aquatic Conserv: Mar Freshwat Ecosyst. 14:299-326. http://dx.doi.org/10.1002/aqc.614

Diaz GA. 2008. The effect of circle hooks and straight J-hooks on the catch rates and numbers of white marlin and blue marlin released alive by the US pelagic longline fleet in the Gulf of Mexico. N Am J Fish Manage. 28:500-506. http://dx.doi.org/10.1577/M07-089.1

Dunn PK. 2004. Occurrence and quantity of precipitation can be modeled simultaneously. Int J Climatol. 24:1231-1239. http://dx.doi.org/10.1002/joc.1063

Dunn PK. 2010. Tweedie: tweedie exponential family models. R package version 2.0.7. Available from: http://www.r-project.org/.

Eschmeyer WN, Fricke R. 2011. Catalog of fishes electronic version (30 November, 2011). Available from: http://research.calacademy.org/research/ichthyology/catalog/fishcatmain. asp. Accessed 22 December, 2011.

Fox J, Weisberg S. 2011. An $\{\mathrm{R}\}$ companion to applied regression. 2nd ed. Thousand Oaks CA: Sage.

Gilman E, Kobayashi D, Chaloupka M. 2008. Reducing seabird bycatch in the Hawaii longline tuna fishery. Endang Species Res. 5:309-323. http://dx.doi.org/10.3354/esr00133

Gilman E, Zollet E, Beverly S, Nakano H, Davis K, Shiode D, Dalzell P, Kinan 1. 2006. Reducing sea turtle by-catch in pelagic longline fisheries. Fish Fish. 7(1):2-23. http://dx.doi. org/10.1111/j.1467-2979.2006.00196.x

Kerstetter DW, Graves JE. 2006a. Effects of circle versus J-style hooks on target and non-target species in a pelagic longline fishery. Fish Res. 80:239-250. http://dx.doi.org/10.1016/j. fishres.2006.03.032

Kerstetter DW, Graves JE. 2006b. Survival of white marlin (Tetrapturus albidus) released from commercial pelagic longline gear in the western North Atlantic. Fish Bull. 104:434-444. 
Largarcha E, Parrales M, Rendón L, Velasquez V, Orozco M, Hall M. 2005. Working with the Ecuadorian fishing community to reduce the mortality of sea turtles in longlines: the first year March 2004-March 2005. Western Pacific Regional Fishery Management Council. 57 p. Lewison RL, Crowder LB, Read AJ, Freeman SL. 2004. Understanding impacts of fisheries bycatch on marine megafauna. Trends Ecol Evol. 19(11):598-604. http://dx.doi.org/10.1016/j. tree.2004.09.004

Lilliefors HW. 1969. On the Kolmogorov-Smirnov test for the exponential distribution with mean unknown. J Amer Statistical Assoc. 64:387-389. http://dx.doi.org/10.2307/2283748

Pacheco JC, Kerstetter DW, Hazin FH, Hazin H, Segundo RSSL, Graves JE, Carvalho F, Travassos PE. 2011. A comparison of circle hook and J-hook performance in a western equatorial Atlantic Ocean pelagic longline fishery. Fish Res. 107:39-45. http://dx.doi. org/10.1016/j.fishres.2010.10.003

Parga ML. 2012. Hooks and sea turtles: a veterinarian's perspective. Bull Mar Sci. 88:731-741. http://dx.dol.org/10.5343/bms.2011.1063

R Development Core Team. 2011. R: a language and environment for statistical computing. R Foundation for Statistical Computing, Vienna, Austria. Available from: http://www.Rproject.org/.

Read AJ. 2007. Do circle hooks reduce the mortality of sea turtles in pelagic longlines? A review of recent experiments. Biol Cons. 135:155:169. http://dx.doi.org/10.1016/j. biocon.2006.10.030

Santos MN, Coelho R, Fernandez-Carvalho J, Amorim S. 2012. Effects of hook and bait on sea turtle catches in an equatorial Atlantic pelagic longline fishery. Bull Mar Sci. 88:683-701. http://dx.doi.org/10.5343/bms.2011.1065

Serafy JE, Kerstetter DW, Rice PH. 2009. Can circle hook use benefit billfishes? Fish Fish. 10: 132-142. http://dx.doi.org/10.1111/j.1467-2979.2008.00298.x

Shono H. 2008. Application of the tweedie distribution to zero-catch data in CPUE analysis. Fish Res. 93: 154-162. http://dx.doi.org/10.1016/j.fishres.2008.03.006

Soykan CU, Moore JE, Zyđelis R, Crowder LB, Safina C, Lewison RL. 2008. Why study bycatch? An introduction to the theme section on fisheries bycatch. Endang Species Res. 5:91-102. http://dx.doi.org/10.3354/esr00175

Ward P, Epe S, Kreutz D, Lawrence E, Robins C, Sands A. 2009. The effects of circle hooks on bycatch and target catches in Australia's pelagic longline fishery. Fish Res. 97:253-262. http://dx.doi.org/10.1016/j.fishres.2009.02.009

Watson JW, Epperly SP, Shah AK, Foster DG. 2005. Fishing methods to reduce sea turtle mortality associated with pelagic longlines. Can J Fish Aquat Sci. 62:965-981. http://dx.doi. org/10.1139/f05-004

Watson JW, Kerstetter DW. 2006. Pelagic longline fishing gear: a brief history and discussion of research efforts to improve selectivity and sustainability. Mar Tech Soc J. 40(3):5-10. http:// dx.doi.org/10.4031/002533206787353259

Yokota K, Kiyota M, Minami H. 2006. Shark catch in a pelagic longline fishery: comparison of circle and tuna hooks. Fish Res. 8:337-341. http://dx.doi.org/10.1016/j.fishres.2006.08.006

Yokota K, Kiyota M, Okamura H. 2009. Effect of bait species and color on sea turtle bycatch and fish catch in a pelagic longline fishery. Fish Res. 97:53-58. http://dx.doi.org/10.1016/j. fishres.2009.01.003

Date Submitted: 11 July, 2011.

Date ACCepted: 17 February, 2012.

Available Online: 20 April, 2012.

Addresses: (RC) 1: Instituto Nacional dos Recursos Biológicos (INRB I.P./IPIMAR), Avenida 5 de Outubro s/n, 8700-305 Olhao, Portugal. 2: Centre of Marine Sciences, University of Algarve (CCMAR), FCT Ed. 7, Campus de Gambelas, 8005-139 Faro, Portugal. (MNS, SA) Instituto Nacional dos Recursos Biológicos (INRB I.P. IPIMAR), Avenida 5 de Outubro s/n, 8700-305 Olhao, Portugal. Corresponding Author: (RC) Email: <rpcoelho@ualg.pt>. 
Appendix 1. List of fish species captured during the present study, with common names, scientific names (with authority), and FAO 3 letter codes. In the category, T-M refers to major targeted species, T-m to minor targeted species, BC-B to teleost bycatch, BC-E to elasmobranch bycatch, D-B to teleost discards, and D-E to elasmobranch discards. Scientific names according to Eschmeyer and Fricke (2011)'s catalog of fishes.

\begin{tabular}{|c|c|c|c|}
\hline$\overline{\text { FAO code }}$ & Category & Scientific name & Common name \\
\hline$\overline{\mathrm{SWO}}$ & T-M & Xiphias gladius Linnaeus, 1758 & Swordfish \\
\hline BET & $\mathrm{T}-\mathrm{m}$ & Thunnus obesus (Lowe, 1839) & Bigeye tuna \\
\hline YFT & $\mathrm{T}-\mathrm{m}$ & Thunnus albacares (Bonnaterre, 1788) & Yellowfin tuna \\
\hline ALB & $\mathrm{BC}-\mathrm{B}$ & Thunnus alalunga (Bonnaterre, 1788) & Albacore \\
\hline AMB & $\mathrm{BC}-\mathrm{B}$ & Seriola dumerili (Risso, 1810) & Greater amberjack \\
\hline BAR & BC-B & Sphyraena viridensis Cuvier, 1829 & Yellowmouth barracuda \\
\hline BUM & $\mathrm{BC}-\mathrm{B}$ & Makaira nigricans Lacépède, 1802 & Blue marlin \\
\hline DOL & $\mathrm{BC}-\mathrm{B}$ & Coryphaena hippurus Linnaeus, 1758 & Dolphinfish \\
\hline LEC & $\mathrm{BC}-\mathrm{B}$ & Lepidocybium flavobrunneum (Smith, 1843) & Escolar \\
\hline OIL & $\mathrm{BC}-\mathrm{B}$ & Ruvettus pretiosus Cocco, 1833 & Oilfish \\
\hline SAI & $\mathrm{BC}-\mathrm{B}$ & Istiophorus platypterus (Shaw, 1792) & Sailfish \\
\hline WAH & $\mathrm{BC}-\mathrm{B}$ & Acanthocybium solandri (Cuvier, 1832) & Wahoo \\
\hline WHM & BC-B & Kajikia albida Poey, 1860 & White marlin \\
\hline $\mathrm{BSH}$ & $\mathrm{BC}-\mathrm{E}$ & Prionace glauca (Linnaeus, 1758) & Blue shark \\
\hline FAL & BC-E & Carcharhinus falciformis (Müller and Henle, 1839) & Silky shark \\
\hline LMA & BC-E & Isurus paucus Guitart, 1966 & Longfin mako \\
\hline OCS & $\mathrm{BC}-\mathrm{E}$ & Carcharhinus longimanus (Poey, 1861) & Oceanic whitetip \\
\hline SMA & BC-E & Isurus oxyrinchus Rafinesque, 1810 & Shortfin mako \\
\hline SPL & BC-E & Sphyrna lewini (Griffith and Smith, 1834) & Scalloped hammerhead \\
\hline SPZ & BC-E & Sphyrna zygaena (Linnaeus, 1758) & Smooth hammerhead \\
\hline ALX & D-B & Alepisaurus ferox Lowe, 1833 & Lancetfish \\
\hline MOX & $\mathrm{D}-\mathrm{B}$ & Mola mola (Linnaeus, 1758) & Sunfish \\
\hline ALV & D-E & Alopias vulpinus (Bonnaterre, 1788) & Common thresher \\
\hline BTH & $\mathrm{D}-\mathrm{E}$ & Alopias superciliosus Lowe, 1841 & Bigeye thresher \\
\hline GAC & $\mathrm{D}-\mathrm{E}$ & Galeocerdo cuvier (Péron and Lesueur, 1822) & Tiger shark \\
\hline MAN & D-E & Myliobatidae & Devil and manta rays \\
\hline PLS & $\mathrm{D}-\mathrm{E}$ & Pteroplatytrygon violacea (Bonaparte, 1832) & Pelagic stingray \\
\hline PSK & D-E & Pseudocarcharias kamoharai (Matsubara, 1936) & Crocodile shark \\
\hline
\end{tabular}

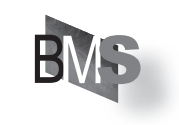

